\title{
Analysis of dermal fibroblasts isolated from neonatal and child cleft lip and adult skin: Developmental implications on reconstructive surgery
}

\author{
VERONIKA ŽIVICOVÁ ${ }^{1,2}$, LUKÁŠ LACINA ${ }^{1,3,4}$, ROSANA MATEU ${ }^{1,7}$, KAREL SMETANA Jr ${ }^{1,3}$, \\ RADANA KAVKOVÁ ${ }^{1,3}$, ELIŠKA DROBNÁ KREJČI ${ }^{1}$, MILOŠ GRIM ${ }^{1}$, ALENA KVASILOVÁ ${ }^{1}$, \\ JIŘÍ BORSKÝ ${ }^{5}$, HYNEK STRNAD $^{6}$, MILUŠE HRADILOVÁ ${ }^{6}$, JANA ŠÁCHOVÁ ${ }^{6}$, \\ MICHAL KOLÁŘ ${ }^{6}$ and BARBORA DVOŘÁNKOVÁ ${ }^{1,3}$
}

\author{
${ }^{1}$ Institute of Anatomy, ${ }^{2}$ Department of Otorhinolaryngology, Head and Neck Surgery, ${ }^{3}$ BIOCEV and \\ ${ }^{4}$ Department of Dermatovenerology, The First Faculty of Medicine, Charles University, 12108 Prague; \\ ${ }^{5}$ Department of Otorhinolaryngology, The Second Faculty of Medicine, Charles University, 15006 Prague; \\ ${ }^{6}$ Institute of Molecular Genetics, Academy of Sciences of the Czech Republic v.v.i., 14220 Prague, Czech Republic
}

Received April 28, 2017; Accepted August 21, 2017

DOI: $10.3892 / \mathrm{ijmm} .2017 .3128$

\begin{abstract}
The nonsyndromic cleft is one of the most frequent congenital defects in humans. Clinical data demonstrated improved and almost scarless neonatal healing of reparative surgery. Based on our previous results on crosstalk between neonatal fibroblasts and adult keratinocytes, the present study focused on characterization of fibroblasts prepared from cleft lip tissue samples of neonates and older children, and compared them with samples isolated from normal adult skin (face and breast) and scars. Although subtle variances in expression profiles of children and neonates were observed, the two groups differed significantly from adult cells. Compared with adult cells, differences were observed in nestin and smooth muscle actin (SMA) expression at the protein and transcript level. Furthermore, fibroblast to myofibroblast differentiation drives effective wound healing and is largely regulated by the cytokine, transforming growth factor- $\beta 1$ (TGF- $\beta 1$ ).
\end{abstract}

Correspondence to: Dr Barbora Dvořánková, BIOCEV, The First Faculty of Medicine, Charles University, Katerinska 32, 12108 Prague, Czech Republic

E-mail: barbora.dvorankova@lf1.cuni.cz

Dr Michal Kolář, Institute of Molecular Genetics, Academy of Sciences of the Czech Republic v.v.i., Vídeňská 1083, 14220 Prague, Czech Republic

E-mail:kolarmi@img.cas.cz

Present address: ${ }^{7}$ Institute of Biochemistry and Experimental Oncology, The First Faculty of Medicine, Charles University, 12108 Prague, Czech Republic

Key words: dermal fibroblasts, myofibroblast, neonatal healing, transforming growth factor- $\beta$, cleft
Dysregulation of the TGF- $\beta$ signalling pathway, including low expression of the TGF- $\beta$ receptor II, may contribute to reducing scarring in neonates. Fibroblasts of facial origin also exhibited age independent differences from the cells prepared from the breast, reflecting the origin of the facial cells from neural crest-based ectomesenchyme.

\section{Introduction}

Nonsyndromic complete or incomplete cleft of the lip and palate is one of the most frequent congenital defects occurring in humans. The incidence of this malformation is influenced by ethnic origin, genetics and by environmental factors (1). This malformation bears the burden of serious medical, aesthetic and psychosocial consequences. Notably, a genetic link between this disorder and risk of cancer in the affected person has been identified (2). Clinical studies have demonstrated that an early surgical repair of the cleft lip results in the most favourable outcome. The cleft should be reconstructed as soon as possible, preferably during the first postnatal week. This strategy appears to be successful in terms of improved healing, as well as minimized scar formation (3-5). However, even this very early timing of cheiloplasty is unable to fully prevent future growth irregularities typical of this malformation $(6,7)$. The excellent results of early cheiloplasty are not surprising, as the prenatal period (the first two trimesters) is associated with the fully regenerative type of healing. Fetal healing in the last trimester of pregnancy, as well as early postnatal healing, is also notably rapid and associated with minimal scar formation $(8,9)$. This marked difference between prenatal/neonatal and adult types of wound healing was widely evaluated, and explained by reduced readiness of fetuses and neonates to development of inflammation. Interleukin-10 (IL-10) inhibiting the immune response is considered the principal cytokine regulating immune response of this stage (10-13).

However, the underlying mechanism of the hypertrophic form of scarring remains unclear with the majority of research 
focusing on the pro-fibrotic growth factor, transforming growth factor- $\beta 1$ (TGF- $\beta 1$ ). TGF- $\beta$ signaling is complex and context dependent. The TGF- $\beta$ family of growth factors is involved in numerous processes in wound healing: Inflammation, angiogenesis stimulation, fibroblast proliferation, collagen synthesis, and deposition and remodelling of the new extracellular matrix. It has been suggested that three known isoforms of TGF- $\beta$ (-1, -2 and -3$)$ exert different temporal effects on wound healing and scarring, and any disruption in their expression pattern may result in hypertrophic scar formation (14). Fibroblasts from hypertrophic scars indeed demonstrated increased TGF- $\beta 1$ expression levels; however, they were also demonstrated to exhibit prolonged expression of the TGF- $\beta$ receptors compared with normal skin, thus enhancing downstream signaling and target gene activation (15). Interestingly, animals lacking SMAD family member (Smad)3, a principal component of the signaling cascade, demonstrated improved wound-healing (achieved by the increased rate of re-epithelization and reduced infiltration of monocytes) (16).

Scarless wound healing is also associated with a reduction of the production of growth factors, which influence fibroblasts and keratinocytes (17), and with changes in extracellular matrix remodelling (18). Fetal keratinocytes differ from their adult counterparts structurally and functionally (19). Suspensions of keratinocytes prepared from neonatal epidermis contain a pool of very small keratinocytes (diameter, $4 \mu \mathrm{m}$ ) that express vimentin (20). This size determinant is a classical marker of clone-forming ability in human keratinocytes (21). These cells appear to be morphologically similar to very small stem cells (22). The ability of small keratinocytes isolated from the neonates to re-epithelise the experimental defect in the confluent culture of epithelial cells improves in vitro when compared with keratinocytes prepared from adult donors (23).

The neonatal fibroblasts are highly active and influence diverse cells in their environment. Notably, adult keratinocytes acquire properties of neonatal keratinocytes, including the occurrence of very small ones under their influence (23). This result is supported by the observation that the neonatal fibroblasts, as well as their products, exert a distinct antifibrotic effect $(19,24)$. This broad activity is to be expected, as fibroblasts are drivers of the embryonic development of epidermal appendages. Under conditions of normal development, fibroblasts determine what the newly formed appendage structure will be, such as hair, tooth, scale or feather (25). Under pathological conditions, cancer-associated fibroblasts are drivers of the aggressiveness of squamous epitheliumoriginated cancer. The crosstalk between epithelial cells and fibroblasts over the course of wound healing and in cancer are quite similar $(26,27)$.

In the present study, the differences between neonatal cleft lip fibroblasts (NCF) and older child cleft lip fibroblasts (OCCF) were investigated, with emphasis on the cleft lip repair strategy and prognosis. Our previous results $(20,23)$ demonstrated a high expression level of nestin, a marker of immature cells, and paradoxically also the presence of smooth muscle actin (SMA), a marker of terminally differentiated cells, in neonatal fibroblasts. Thus, a detailed analysis of the expression levels of nestin and SMA was performed in neonates. In addition, the neonatal dermal fibroblasts were further investigated with a focus on possible overlap with a molecular signature typical for neural crest-originated hair follicle stem cells (20). This aspect seems to be developmentally relevant, with respect to the origin of (ecto-) mesenchymal cells from the neural crest in the head region. These data include analysis of expression profiles of neonatal, child, and adult fibroblasts as well as the fibroblasts harvested from scars.

\section{Materials and methods}

Isolation of cells and cell culture. Dermal fibroblasts were isolated from residual skin during cleft lip reconstructive surgery as follows: Neonates (age, 1-16 days), 24 samples; older children (age, 3 months-6 years), 8 samples; control samples of adults (age, 23-77 years), 8 samples (4 from the breast and 4 from the face); scars from the trunk of adult patients (age, 38 and 78 years), 2 samples. The skin samples were acquired at the Ear, Nose and Throat (ENT) Department of the University Hospital in Motol and from the Department of Plastic Surgery, University Hospital Královské Vinohrady (Prague, Czech Republic). The samples of the scars were obtained from the Department of Dermatovenerology, General University Hospital (Prague, Czech Republic). All samples were collected under Local Ethics Committee approval in accordance with the ethical standards of the Institutional and National Research Committee, and according to the 1964 Helsinki declaration and its later amendments or comparable ethical standards. The informed consent was obtained from all individual participants, or their legal representatives in the case of minors, included in the present study. Certain samples were cryoprotected using Tissue-Tek (Sakura Finetek Europe B.V., Zoeterwoude, The Netherlands) and frozen in liquid nitrogen. The $10 \mu \mathrm{m}$ sections were prepared using CryoCut (Reichert-Jung, Viena, Austria) and were used for immunohistochemistry. The processing of skin samples for cell cultivation and the isolation of fibroblast populations were described in detail by Krejčí et al (20). Residual skin samples were cut to very small sections (up to $1 \mathrm{~mm}^{3}$ ) which were shortly digested in $0.25 \%$ trypsin (Sigma-Aldrich, Prague, Czech Republic) for $20 \mathrm{~min}$ at $37^{\circ} \mathrm{C}$ and then transferred into CellBIND 6-well plates (Corning, Schiphold Rijk, The Netherlands). Skin explants were cultured in minimal volume of Dulbecco's modified Eagle's medium (DMEM) supplemented with antibiotics (penicillin $10 \mathrm{U} / \mathrm{ml}$ and streptomycin $100 \mu \mathrm{g} / \mathrm{ml}$ ) $10 \%$ of fetal bovine serum (FBS) (all from Biochrom, Berlin, Germany) and $100 \mu \mathrm{g} / \mathrm{ml}$ gentamycin (Sigma-Aldrich) at $37^{\circ} \mathrm{C}$ and $5 \% \mathrm{CO}_{2}$ in humidified incubator. Fibroblasts emigrated from tissue samples were harvested by $1: 1 \mathrm{v} / \mathrm{v}$ mixtures of $0.25 \%$ trypsin and $0.02 \%$ ethylenediaminetetraacetic acid (EDTA; Biochrom, Berlin, Germany). Isolated fibroblasts were characterized by their negativity for leukocyte marker, cluster of differentiation (CD)45, melanocyte markers (melanoma antigen A and HMB-45), keratins, and positivity for vimentin. The absence of bacterial contamination was continuously controlled by visualization under a microscope. The absence of mycoplasma was verified by staining with 4',6-diamidino-2-phenylindole (DAPI; Merck KGaA, Darmstadt, Germany). Routinely, all fibroblast populations were cultured in DMEM supplemented with antibiotics (penicillin $10 \mathrm{U} / \mathrm{ml}$ and streptomycin $100 \mu \mathrm{g} / \mathrm{ml}$ ) and 10\% FBS at $37^{\circ} \mathrm{C}$ and $5 \% \mathrm{CO}_{2}$ in a humidified incubator. 
Table I. Antibodies used for immunohistochemical, immunocytochemical and western blot analysis.

\begin{tabular}{|c|c|c|c|}
\hline Primary antibody & Supplier (location) & $\begin{array}{l}\text { Secondary antibody/ } \\
\text { fluorochrome }\end{array}$ & Supplier (location) \\
\hline $\begin{array}{l}\text { Nestin/M } \\
\text { immunohistochemistry } \\
\text { MAB5326; 1:200 }\end{array}$ & $\begin{array}{l}\text { Merck KGaA } \\
\text { (Darmstadt, Germany) }\end{array}$ & $\begin{array}{l}\text { Goat anti-mouse/TRITC } \\
115-025-044 ; 1: 30\end{array}$ & $\begin{array}{l}\text { Jackson ImmunoResearch } \\
\text { Laboratories, Inc. } \\
\text { (West Grove, PA, USA) }\end{array}$ \\
\hline $\begin{array}{l}\text { Nestin/P } \\
\text { HPA007007; 1:200 } \\
\text { Oct-4/P } \\
\text { P0056; } 1: 200\end{array}$ & $\begin{array}{l}\text { Sigma-Aldrich } \\
\text { (Merck KGaA; } \\
\text { Darmstadt, Germany) }\end{array}$ & $\begin{array}{l}\text { Swine anti-rabbit/FITC } \\
\text { F0205; } 1: 30\end{array}$ & $\begin{array}{l}\text { Dako (Agilent Technologies, Inc., } \\
\text { Santa Clara, CA, USA) }\end{array}$ \\
\hline $\begin{array}{l}C D 45 / M \\
\text { C7556; } 1: 50 \\
\text { Vimentin/M } \\
\text { M0725; } 1: 50 \\
\text { Smooth muscle actin/M } \\
\text { M0851; } 1: 50\end{array}$ & $\begin{array}{l}\text { Dako (Agilent Technologies, Inc., } \\
\text { Santa Clara, CA, USA) }\end{array}$ & $\begin{array}{l}\text { Goat anti-mouse/TRITC } \\
\text { T5393; } 1: 30\end{array}$ & $\begin{array}{l}\text { Sigma-Aldrich (Merck KGaA; } \\
\text { Darmstadt, Germany) }\end{array}$ \\
\hline $\begin{array}{l}\text { Nanog/M } \\
\text { AF1997; 1:15 }\end{array}$ & $\begin{array}{l}\text { R\&D Systems, Inc. } \\
\text { (Minneapolis, MN, USA) }\end{array}$ & $\begin{array}{l}\text { Donkey anti-goat/TRITC } \\
\text { Sc-2094; 1:200 }\end{array}$ & $\begin{array}{l}\text { Santa Cruz Biotechnology, Inc. } \\
\text { (Dallas, TX, USA) }\end{array}$ \\
\hline $\begin{array}{l}\text { Melan A/M } \\
\text { MA5-14168; 1:100 } \\
\text { HMB-45 (anti- } \\
\text { melanosome)/M } 081050 \\
\text { ready to use antibody }\end{array}$ & $\begin{array}{l}\text { Invitrogen (Thermo Fisher } \\
\text { Scientific, Inc., } \\
\text { Waltham, MA, USA) }\end{array}$ & $\begin{array}{l}\text { Goat anti-mouse/TRITC } \\
\text { 115-025-044; 1:30 }\end{array}$ & $\begin{array}{l}\text { Sigma-Aldrich (Merck KGaA; } \\
\text { Darmstadt, Germany) }\end{array}$ \\
\hline $\begin{array}{l}\text { Wide spectrum } \\
\text { cytokeratin/P } \\
\text { Ab9377; } 1: 100\end{array}$ & Abcam (Cambridge, UK) & $\begin{array}{l}\text { Swine anti-rabbit/FITC } \\
\text { F0205; } 1: 30\end{array}$ & $\begin{array}{l}\text { Dako (Agilent Technologies, Inc., } \\
\text { Santa Clara, CA, USA) }\end{array}$ \\
\hline $\begin{array}{l}\alpha-T u b u l i n \text { (loading control) } \\
\text { T9026; 1:500 }\end{array}$ & $\begin{array}{l}\text { Sigma-Aldrich (Merck KGaA; } \\
\text { Darmstadt, Germany) }\end{array}$ & $\begin{array}{l}\text { Goat anti-mouse/ } \\
\text { horseradish peroxidase } \\
\text { Sc-516102; } 1: 2,000\end{array}$ & $\begin{array}{l}\text { Santa Cruz Biotechnology, Inc. } \\
\text { (Dallas, TX, USA) }\end{array}$ \\
\hline
\end{tabular}

TRITC, tetramethylrhodamine; FITC, fluorescein isothiocyanate.

Immunocytochemistry. Fibroblasts were inoculated at a density of 1,500 cells $/ \mathrm{cm}^{2}$ on the coverslips, placed in 8-well dishes (Nunc; Thermo Fisher Scientific, Inc., Waltham, MA, USA) and cultured in DMEM for 4 days (for nestin, octamerbinding transcription factor 4 and Nanog) or to full confluence (generally 7 day for SMA). The culture medium was refreshed every two days.

Fibroblasts that were adherent to coverslips were fixed by $5 \%(\mathrm{w} / \mathrm{v})$ paraformaldehyde in phosphate-buffered saline (PBS; pH 7.2), washed three times with PBS and permeabilized with $0.05 \%$ Triton X-100 (Sigma-Aldrich; Merck $\mathrm{KGaA}$ ). The non-specific binding of immunoglobulins via $\mathrm{Fc}$ receptors was blocked by $3.3 \%$ non-immune porcine serum (Dako; Agilent Technologies, Inc., Santa Clara, CA, USA). The employed antibodies are presented in Table I (antibody dilutions were according to the supplier's instructions). The specificity of the immunocytochemical reaction was evaluated by use of isotype controls or irrelevant antibodies rather than specific antibodies. The cell nuclei were counterstained with DAPI. The specimens were mounted in Vectashield (Vector Laboratories, Ltd., Peterborough, UK) and analyzed using an Eclipse 90i fluorescence microscope (Nikon Corp., Tokyo, Japan) equipped with a ProgRes MF Cool camera (Jenoptik Optical Systems GmbH, Jena, Germany) and NIS-Elements AR4.40.00 computer-assisted image analysis system (Laboratory Imaging, Prague, Czech Republic).

Western blot analysis. The cells of each fibroblast population were seeded at a density of 1,000 cells $/ \mathrm{cm}^{2}$ into $10-\mathrm{cm}$ diameter Petri dishes (Corning, Inc., Corning, NY, USA) and cultured for 7 days (95-100\% confluence). The culture medium was refreshed every two days. The cell lysates were harvested according to the standard protocol in NP-40 cell lysis buffer (Thermo Fisher Scientific, Inc.). The supernatant was collected into a fresh microtube containing Protease Inhibitor Cocktail (Sigma-Aldrich; Merck KGaA). The total protein concentration was detected using the Bradford method for protein quantitation (28). Samples were resolved by 1-dimensional sodium dodecyl sulfate-polyacrylamide gel electrophoresis (SDS-PAGE) gels according to standard techniques. Equal quantities of total protein $(10 \mu \mathrm{g})$ were subjected to $12 \%$ SDS-PAGE (electrophoresis for $60 \mathrm{~min}, 100 \mathrm{~V}$, in cold 
room at $4^{\circ} \mathrm{C}$ ) and transferred onto polyvinylidene difluoride membranes. The membranes were subsequently blocked with 5\% goat serum (Sigma-Aldrich) for $1 \mathrm{~h}$ and probed with specific SMA primary antibody (dilution, 1:1,000; overnight at $4^{\circ} \mathrm{C}$ ), followed by the appropriate horseradish peroxidase-conjugated secondary antibody (dilution, 1:5,000; $60 \mathrm{~min}$ at room temperature). Proteins were detected using the KPL TrueBlue blotting detection reagents (BioVendor Laboratory Medicine, Inc., Brno, Czech Republic).

Detection of IL-6, IL-8 and TGF- $\beta 1$ by enzyme-linked immunosorbent assay (ELISA). The cells of each fibroblast population were seeded at a density of 30,000 cells $/ \mathrm{cm}^{2}$ into two wells (two technical replicates) of a 6-well plate (TPP Techno Plastic Products AG, Trasadingen, Switzerland). The next day, the culture medium was removed and $2.5 \mathrm{ml}$ fresh DMEM was placed in each well. After $24 \mathrm{~h}$, the conditioned medium was collected (each replicate separately), filtered through a $0.2-\mu \mathrm{m}$ microstrainer to remove the floating cells, divided into $500-\mu 1$ aliquots and stored at $-20^{\circ} \mathrm{C}$. Using Human IL-8, IL-6 and TGF- $\beta 1$ kits (cat. nos. El1008-1, El1006-1 and ET3102-1; BioVendor Laboratory Medicine Inc.), the concentration of the proteins was detected according to the producer's instructions. The final intensity of yellow coloration was measured at a wavelength of $450 \mathrm{~nm}$ using a Universal Microplate Reader (Bio-Tek Instruments, Inc., Winooski, VT, USA).

Cell proliferation assay and TGF- $\beta$ treatment/inhibition. Fibroblasts from different donors [neonates with cleft lip with $(n=2)$ or without $(n=2)$ family history; children, $n=2$; adult facial $(n=2) /$ breast $(n=2)$ fibroblasts] were seeded at a density of 750 cells/well in 96-well plates. To achieve full adherence, cells were incubated at $37^{\circ} \mathrm{C}$ overnight in DMEM with $10 \% \mathrm{FBS}$. The next day, the culture medium was changed to media containing following active substances. TGF- $\beta$ signaling blockade was performed selectively using small drug inhibitor SB-431542 (Sigma-Aldrich) at a concentration of $10 \mu \mathrm{mol} / 1$, which completely abrogates phosphorylation of SMAD2 in fibroblasts (29). The control cells were maintained in DMEM plus $10 \%$ FBS. Recombinant human TGF- $\beta 1$, TGF- $\beta 2$ and TGF- $\beta 3$ (all Sigma-Aldrich) were dissolved in $4 \mathrm{mM} \mathrm{HCl}$ with $0.1 \%$ of bovine serum albumin at a concentration $10 \mathrm{ng} / \mu \mathrm{l}$ and, for the experiments, they were used at a final concentration of $10 \mathrm{ng} / \mathrm{ml}$ DMEM. Cell proliferation was continuously monitored using an IncuCyte ZOOM Kinetic live cell imaging system (Essen BioScience, Ann Arbor, MI, USA) and measured as the phase object confluence percentage. All experiments were performed in triplicate and monitored for one week. Graphs were plotted and aligned (at $15 \%$ confluence) in the $\mathrm{R}$ statistical environment. The growth of cells was compared after $96 \mathrm{~h}$, where the growth curves were in the log phase.

Microarray analysis. The cells of each fibroblast population were seeded at a density of 1,000 cells $/ \mathrm{cm}^{2}$ into two $6-\mathrm{cm}$ diameter Petri dishes (Corning, Inc.) and cultured for 7 days (95-100\% confluence). The culture medium was changed every two days and $24 \mathrm{~h}$ before harvest. The cells were washed twice with Dulbecco's PBS (Biochrom GmbH, Berlin, Germany), and $350 \mu \mathrm{l}$ buffer RLT (Qiagen GmbH, Hilden, Germany) and 2-mercaptoethanol (Sigma-Aldrich; Merck KGaA) was added.
Using automatic pipette, the cell lysates (two technical replicates of each population) were collected into small Eppendorf tubes, immediately frozen and stored at $-80^{\circ} \mathrm{C}$.

Total RNA was isolated using an RNeasy micro kit (cat. no. 74004; Qiagen, Inc., Valencia, CA, USA) according to the procedure for animal cells. The quantity of RNA was measured using a NanoDrop ND-1000 spectrophotometer (NanoDrop Technologies; Thermo Fisher Scientific, Inc.). The quality of the RNA was analyzed using an Agilent 2100 Bioanalyzer (Agilent Technologies, Inc.). The RNA samples with an RNA integrity number $>9$ were used for further analysis.

Illumina HumanHT-12 v4 chips (Illumina, Inc., San Diego, CA, USA) were used for the microarray analysis according to the standard protocol. Total RNA (150 ng) was amplified using an Illumina TotalPrep RNA amplification kit (cat. no. AMIL1791; Ambion; Thermo Fisher Scientific, Inc.), and $0.75 \mu \mathrm{g}$ of the amplified RNA was hybridized on the chips according to the manufacturer's protocol. The analysis was performed in three biological replicates for the adult scar fibroblast group, nine biological (plus three technical) replicates for the adult breast fibroblast group, five biological replicates for the adult facial fibroblast group, seven biological (plus six technical) replicates for the OCCF group, and 24 biological (plus 18 technical) replicates for the NCF group.

The raw data was preprocessed using GenomeStudio software (version 1.9.0.24624; Illumina, Inc.) and further analyzed using the oligo (30) and limma (31) packages of the Bioconductor (32) within the R environment (33). Briefly, the transcription profiles were background corrected using a normal-exponential model, quantile normalized and variance stabilized using base 2 logarithmic transformation. A moderated t-test was used to detect differentially expressed transcripts (after fitting a linear model I group * gender within limma). A Storey's q-value of $<0.1$ (34) and a minimum of a 2 -fold change in expression intensity were required to consider genes as differentially transcribed. The Minimum Information About a Microarray Experiment compliant data was deposited to the ArrayExpress database (accession no. E-MTAB-5385).

Gene set enrichment analysis (GSEA) was performed using Fisher's exact test on gene sets defined by Kyoto Encyclopedia of Genes and Genomes (KEGG) pathways (35) and the terms of the Gene Ontology (GO) (36). The gene sets were compared with the set of differentially expressed genes in the respective comparisons. Only the KEGG pathways (resp. GO terms) with GSEA p $<0.005$, a minimal overlap of six genes, and odds ratio $>3$ (resp. five) were considered to be statistically significant.

Statistical analysis. Statistical analysis was performed using Paleontological Statistics (version 3.14; University of Oslo, Oslo, Norway) and the nonparametric Kruskal-Wallis test (by ranks) was performed for pairwise comparisons. $\mathrm{p}<0.05$ was considered to indicate a statistically significant difference.

\section{Results}

Nestin and SMA are expressed by neonatal fibroblasts. While almost all NCF isolates exhibited distinct signals for nestin, the signal in the OCCF group was strongly reduced and the number of nestin-positive cells in the samples from normal adult face or breast tissue was negligible (Fig. 1A-C). Similar profiles were 
A

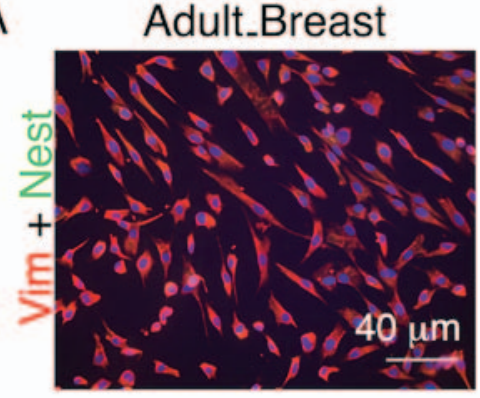

C

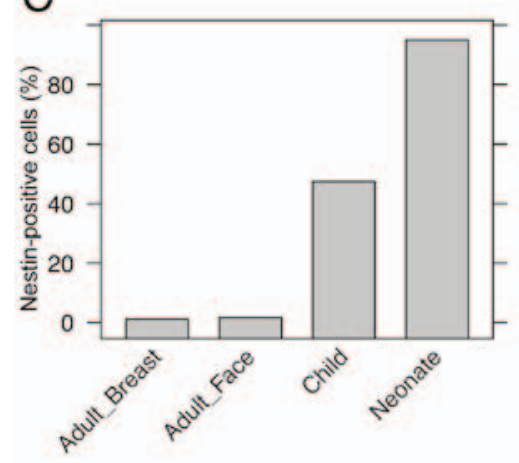

B

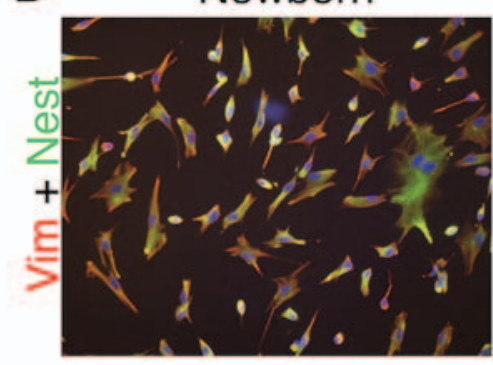

D

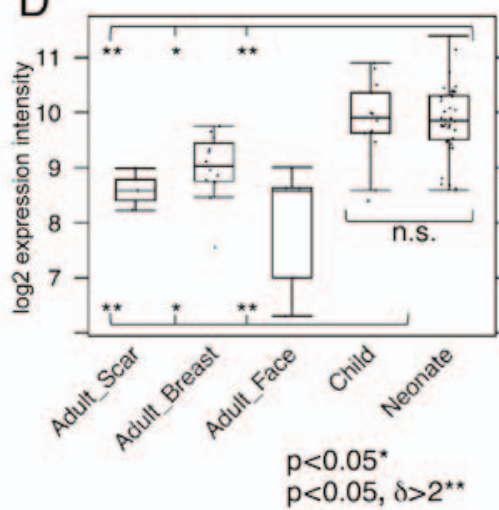

Figure 1. Comparison of nestin expression in adult, child and neonatal fibroblasts. Immunocytochemical detection of nestin-positive cells in (A) adults and (B) neonates, and (C) their percentage quantification in all studied fibroblasts. (D) Data from expression profiling. Potential statistical significance between tested types of fibroblasts was marked by use of line segments connecting tested cell types; ${ }^{*}$ p $<0.05$ indicates a statistically significant differences; ${ }^{* *}$ p $<0.05$ indicates a statistically significant difference and a minimum of a 2-fold $(\delta>2)$ change. Vim, vimentin; Nest, nestin; n.s., not significant.
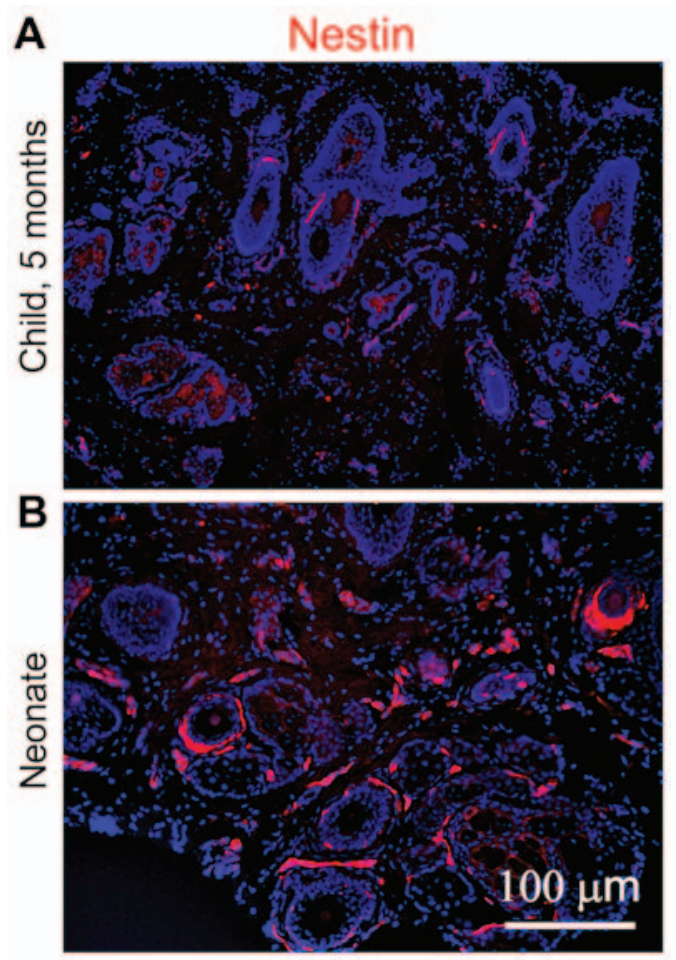

Figure 2. Expression of nestin in dermis samples obtained from (A) a child and (B) a neonate. Red signal detects fibroblasts positive for nestin. The nuclei of all cells are blue because they were counterstained with 4',6-diamidino2-phenylindole (DAPI).

observed in the transcriptomics data (Fig. 1D) and confirmed in the sections of the human dermis (Fig. 2). The high incidence of fibroblasts expressing nestin in NCF populations corresponded well with the presence of cells with nuclei that were positive for pluripotency markers, Oct4 and Nanog (Fig. 3A-C). This was observed in cultures with or without SMA exhibiting myofibroblasts. No obvious correlation of nestin, Nanog homeobox and POU class 5 homeobox 1 was detected in transcriptomic data (Fig. 3D and E). In comparison to the fibroblasts isolated from normal adult breast and face tissue samples, the NCF and OCCF groups often exhibited signals for SMA, as detected by immunocytochemistry (Fig. 4A and B). However, the expression level of this protein was even stronger, as western blot analyses of NCF lysates exhibited SMA even in the populations that were morphologically negative for the presence of SMA in its typical fibrillary pattern (also termed stress fibres) as detected by immunofluorescence (Fig. 4C). Overall, 50\% of NCF and OCCF samples exhibited signals for fibrillar SMA (Fig. 4D). The transcriptomic activity of actin $\alpha 2$, smooth muscle, aorta, the gene coding for SMA, was also elevated in the NCF and OCCF groups when compared with adult cells, predominantly from the face (Fig. 4E). In addition, the NCF and OCCF groups expressed a greater quantity of actin $\gamma 2$, smooth muscle, enteric when compared with adult breast or scar fibroblast samples (Fig. 4F).

Expression levels of IL-6 and IL-8 differ between fibroblast groups. As it is known that the transition of fibroblasts to SMA-positive myofibroblasts is strongly stimulated by TGF- $\beta 1$ (37), this cytokine was measured by ELISA in the media conditioned by all of the investigated fibroblasts. No significant differences between the NCF and OCCF groups, as well as the adult fibroblasts were identified in the expression 
A

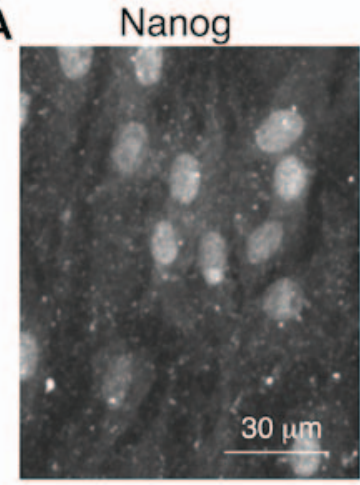

D

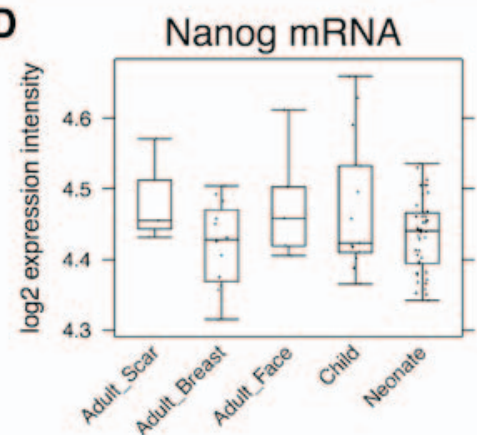

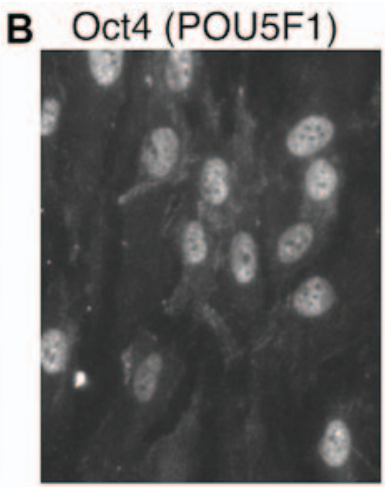
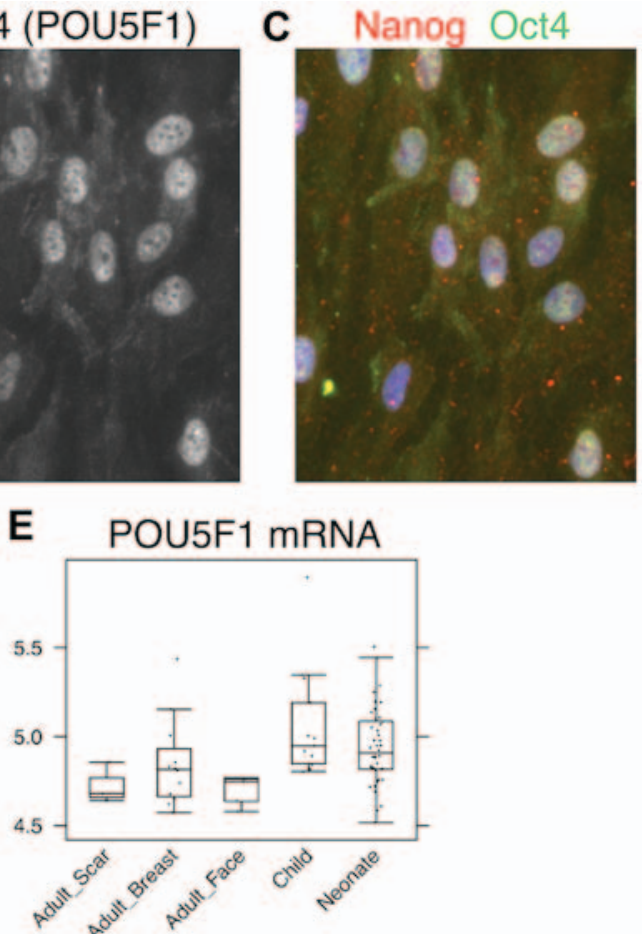

Figure 3. Detection of Nanog and Oct4 was performed by double staining immunocychemistry at single-cell level in neonatal fibroblasts that were negative for smooth muscle actin. Visualization of Nanog in (A) red tetramethylrhodamine channel, (B) Oct4 in green fluorescein isothiocyanate channel and (C) merged figure. (D and E) Data from expression profiles, where no significant differences were identified. Oct4, octamer-binding transcription factor 4.

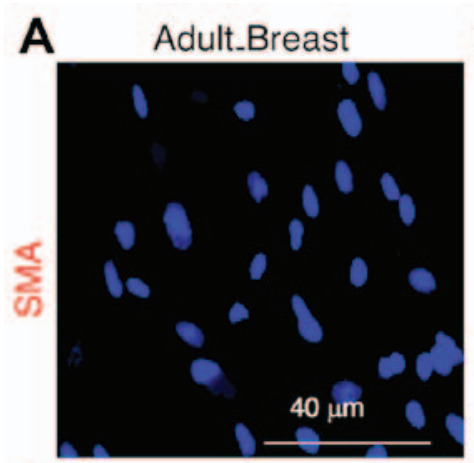

D

\begin{tabular}{|lccc|}
\hline & SMA+ & SMA- & Total \\
\hline Adult Breast & 0 & 3 & 3 \\
\hline Adult Face & 1 & 4 & 5 \\
\hline Child & 4 & 4 & 8 \\
\hline Neonate & 12 & 12 & 24 \\
\hline
\end{tabular}

B

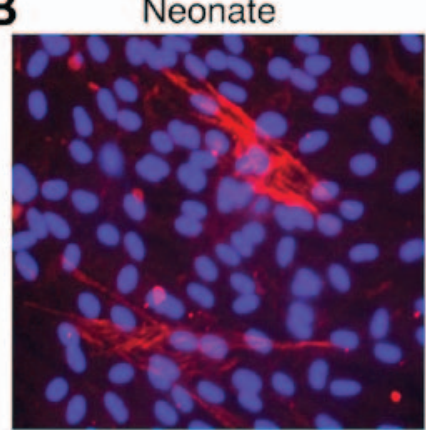

E

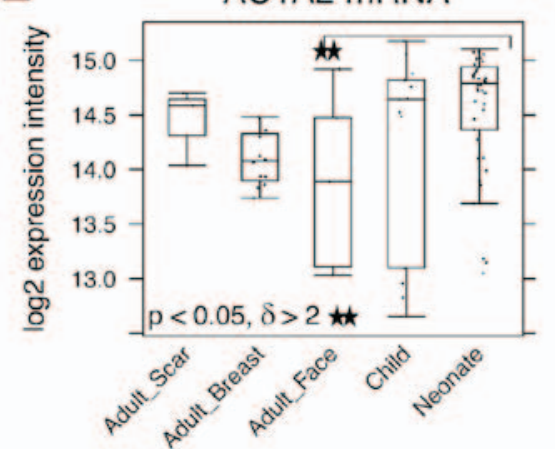

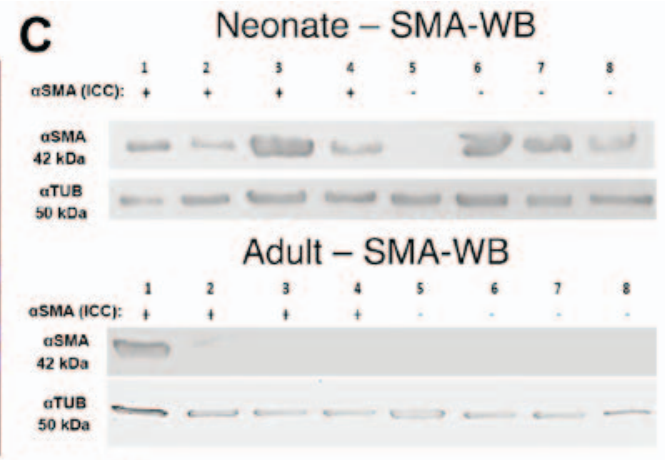

F

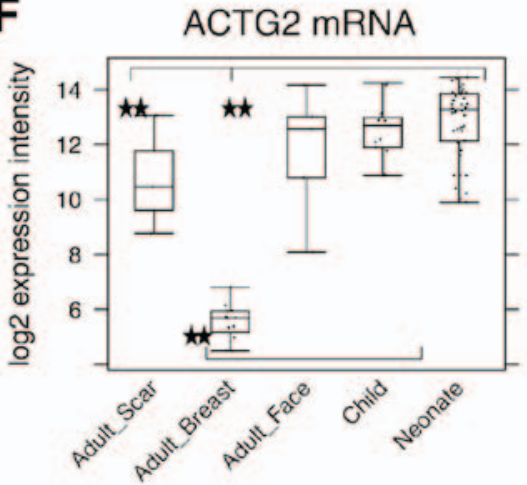

Figure 4. Expression levels of SMA in (A) adult breast and (B) neonatal fibroblasts as quantified by immunohistochemistry and (C) WB analysis of representative neonatal and adult fibroblasts. (D) Proportion of SMA-positive cells detected by immunocytochemistry. (E) ACTA2 and (F) ACTG2 gene activities are also demonstrated. Potential statistical significance between tested types of fibroblasts was marked by use of line segments connecting tested cell types; ${ }^{* *}$ p $<0.05$ indicates a statistically significant difference and a minimum of a 2-fold $(\delta>2)$ change. SMA, smooth muscle actin; WB, western blotting; ACTA2, actin $\alpha 2$, smooth muscle, aorta; ACTG2, actin $\gamma 2$, smooth muscle, enteric; $\alpha$ TUB, $\alpha$ tubulin; mRNA, messenger RNA.

level of TGF- $\beta 1$ (data not shown). IL-6, IL-8 and C-X-C motif chemokine ligand-1 (CXCL-1) are produced by fibroblasts during the course of wound healing, as well as by cancer-associated fibroblasts and they influence the low differentiation 
A

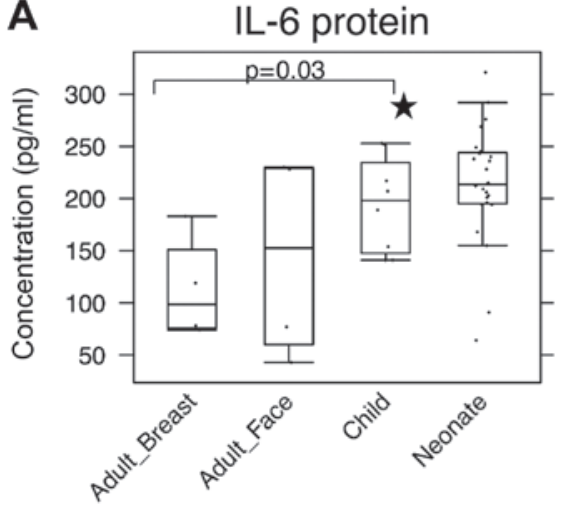

B

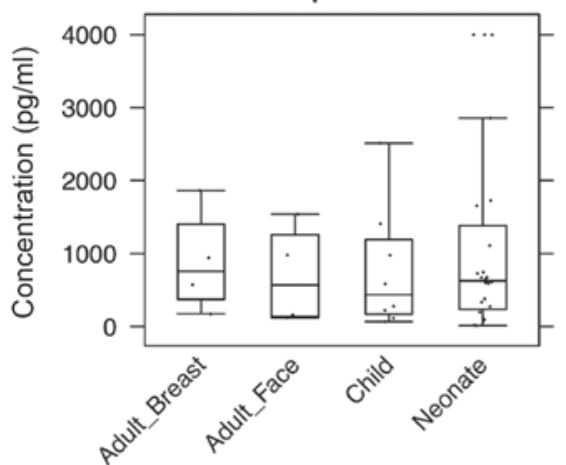

C

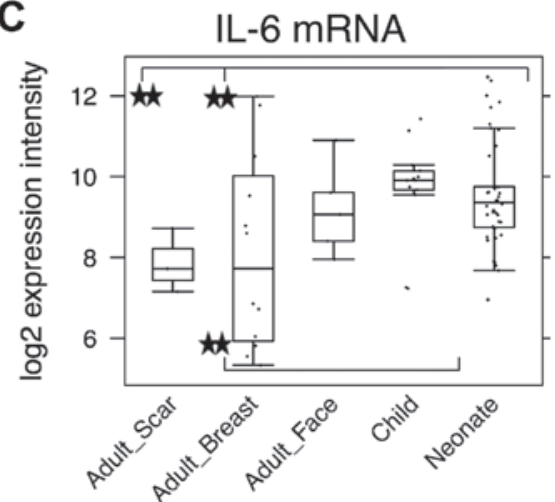

D IL-8 mRNA

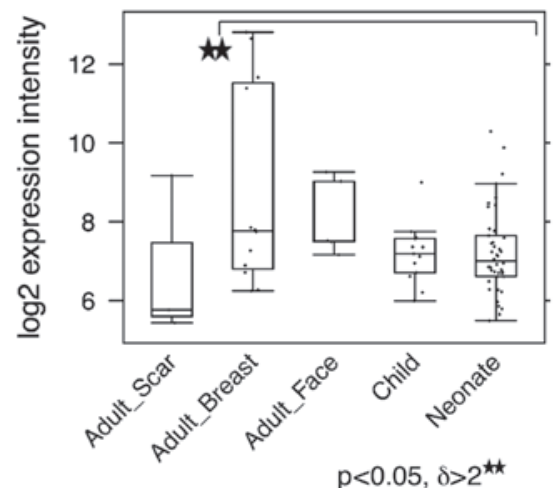

Figure 5. Production of (A) IL-6 and (B) IL-8 to cultivation media measured by enzyme-linked immunosorbent assay (ELISA) compared with detection of (C) $I L-6$ and (D) $I L-8$ gene activity. Potential statistical significance between tested types of fibroblasts was marked by use of line segments connecting tested cell types; ${ }^{*}$ p $<0.05$ and ${ }^{* *}$ p $<0.05$ indicates a statistically significant difference and a minimum of a 2 -fold $(\delta>2)$ change. IL, interleukin.

status of normal human keratinocytes (38). Production of IL-6 by NCF was significantly higher than by adult fibroblasts (Fig. 5A). No difference in production of IL-8 among the investigated cell types was observed (Fig. 5C). In the case of CXCL-1, none of the evaluated fibroblast types produced detectable quantities of this chemokine to the medium (data not shown). At the transcript level, NCF and, in particular, OCCF transcribed the $I L-6$ gene more than the adult breast fibroblasts [3-fold upregulated; $(\mathrm{p}<0.05)$ (Fig. 5B)]. By contrast, the $I L-8$ gene was expressed to a lesser extent in the NCF and OCCF groups when compared with in adult breast fibroblasts [threefold downregulated; $(\mathrm{p}<0.05$, resp. $\mathrm{p}=0.06)$ (Fig. 5D)]. No change in CXCL1 expression was detected.

Transcription profiling reveals the involvement of TGF- $\beta$ signaling. NCF group differed from adult cells isolated from the face in transcription activity of hundreds of genes. Similar differences were identified between the OCCF group and fibroblasts prepared from adult face skin, and in comparison of $\mathrm{NCF}$ and OCCF groups, respectively, to the fibroblasts isolated from the chest (Fig. 6; supplementary data, https://www.ebi. ac.uk/arrayexpress/experiments/E-MTAB-5385/). While the changes between the NCF and OCCF groups, and adult breast cells were dominated by the changes in signaling pathways, the differences between the NCF and OCCF groups, and adult facial fibroblasts were dominated by the changes in metabolic pathways (https://www.ebi.ac.uk/arrayexpress/experiments/E-MTAB-5385/). This fact reflects the common ontological origin of the facial cells (NCF, OCCF and adult facial fibroblasts), which differs from the adult breast fibroblast. It is widely accepted that facial mesenchyme is originated from the neural crest (termed ectomesenchyme) and so it differs, concerning its origin, from fibroblasts in other parts of the body (25). The transcriptomic analysis indeed demonstrated a difference between fibroblasts prepared from the face and breast in 364 genes (https://www.ebi.ac.uk/arrayexpress/experiments/E-MTAB-5385/). The differentially expressed genes included members of the homeobox gene family (Fig. 7) (39). Their expression intensity was independent of the disease/cleft status.

Among the most dysregulated KEGG pathways, which distinguished the adult samples and neonate/child samples were advanced glycation endproducts-receptor for advanced glycation endproducts (AGE-RAGE) signaling (hsa04933), TGF- $\beta$ signaling (hsa04350) and TNF signaling pathway (hsa04668). Closer analysis of the AGE-RAGE signaling pathway revealed that the changes in this pathway accumulate in its TGF- $\beta$ module (TGF- $\beta 2$, TGF- $\beta 3$ and TGF- $\beta$ R2) (Fig. 8) and inflammation-associated modules (IL-8, matrix metalloproteinase-2 and vascular endothelial growth factor A). Thus, there was significant enrichment of differentially expressed genes involved in TGF- $\beta$ signaling. These findings were supported by the GSEA analysis on the GO terms. In the comparison of adult facial fibroblasts to NCF, pronounced changes were observed in the term, GO:0071604, TGF- $\beta$ production, with large changes in transcription of the genes CD2 associated protein $(C D 2 A P), \mathrm{CD} 34$ molecule $(C D 34)$, hypoxia inducible factor $1 \alpha$ subunit $(H I F 1 A)$, CD24 molecule (CD24), 

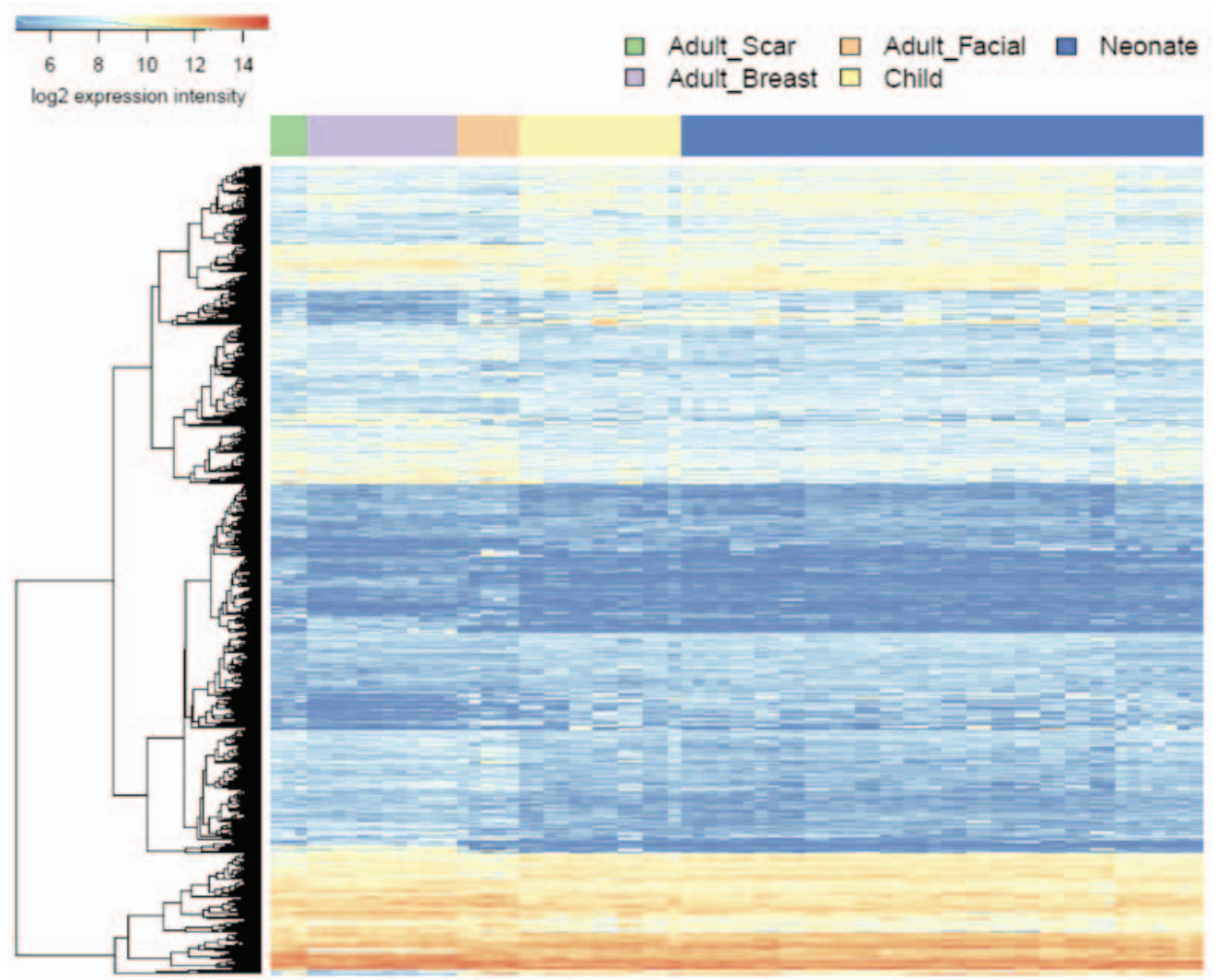

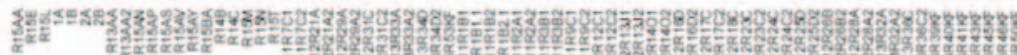

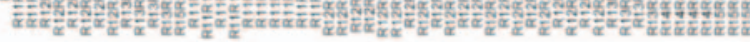

Figure 6. Heat map demonstrating differences in the expression profiles of all of the investigated types of fibroblast.

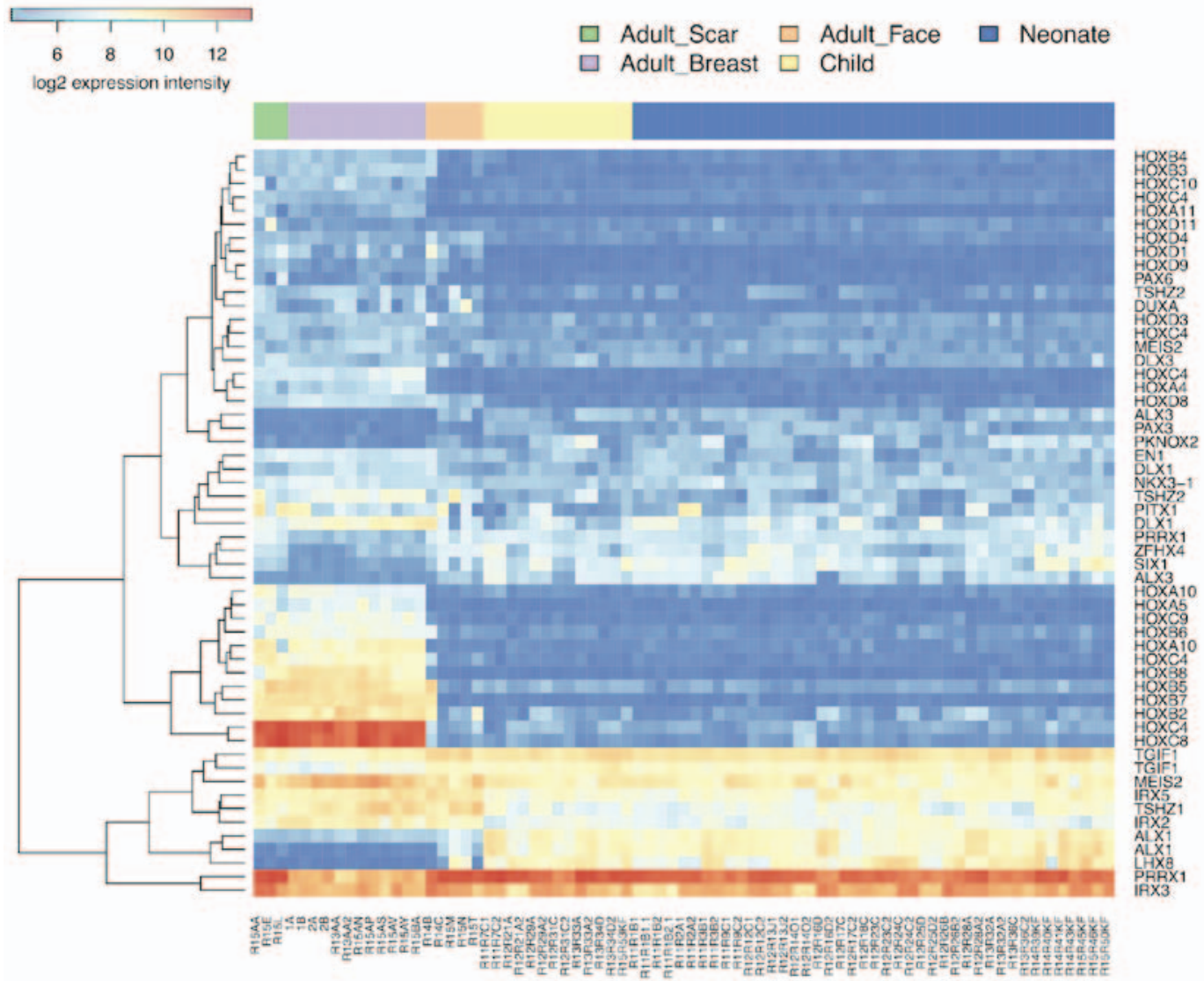

Figure 7. Heat map demonstrating the expression of HOX genes in all of the evaluated types of fibroblast. 
A TGF- $\beta 2$

D TGF- $\alpha$

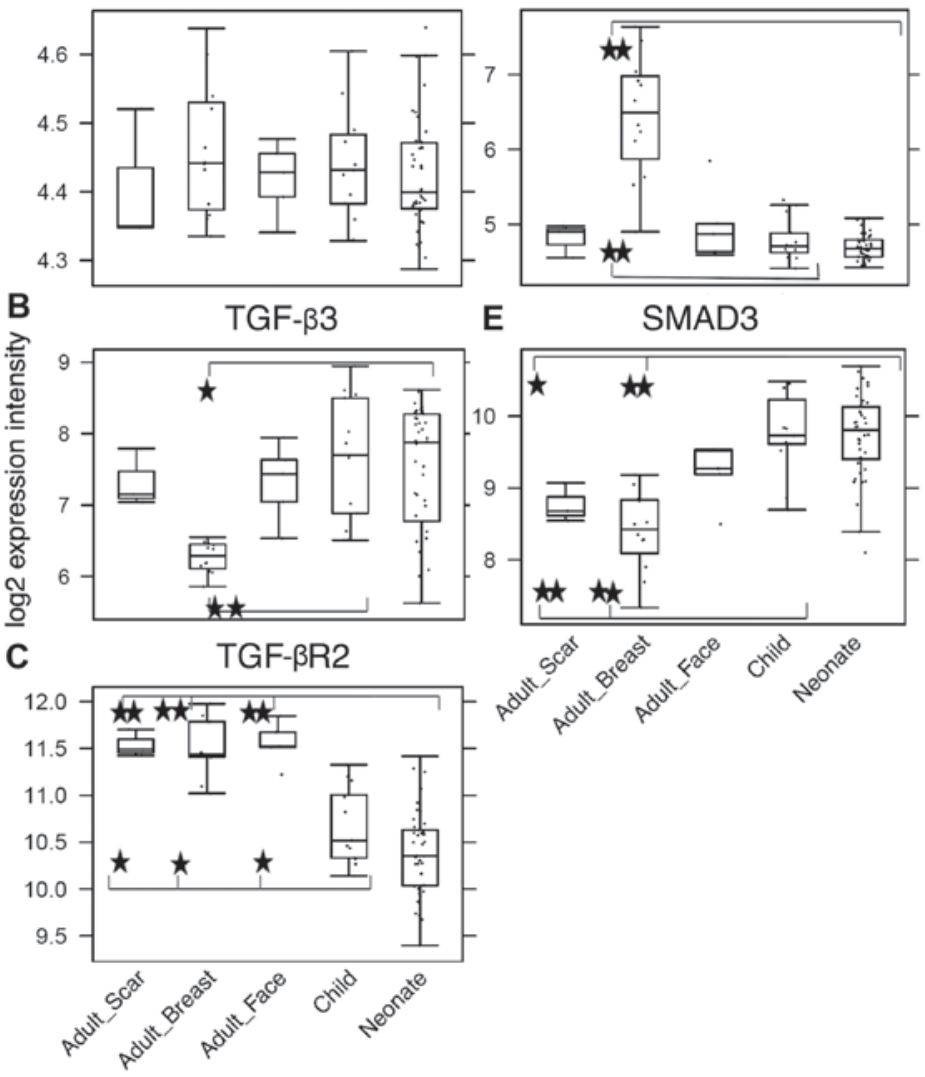

Figure 8. Detection of (A) $T G F-\beta 2$, (B) $T G F-\beta 3$, (C) $T G F-\beta R 2$ receptor, (D) $T G F-\alpha$ and (E) SMAD3 gene activity in all of the tested types of fibroblast Potential statistical significance between tested types of fibroblasts was marked by use of line segments connecting tested cell types; ${ }^{*} \mathrm{p}<0.05$ and ${ }^{* *} \mathrm{p}<0.05$ indicates a statistically significant difference and a minimum of a 2 -fold $(\delta>2)$ change. TGF- $\beta 2$, transforming growth factor- $\beta 2$; TGF- $\beta$ R2, transforming growth factor- $\beta$ receptor 2 ; TGF- $\alpha$, transforming growth factor- $\alpha$; SMAD3, SMAD family member 3.

prostaglandin-endoperoxide synthase 2 (PTGS2) and MET proto-oncogene, receptor tyrosine kinase $(M E T)$. Additionally, GO term analysis revealed shared changes in the expression of genes involved in skeletal development, mesenchyme proliferation and microtubule polymerization. Adult breast fibroblasts differed from the neonatal and child facial fibroblasts in the expression of genes connected to chemotaxis and organ development, including heart morphogenesis and neural crest development, (https://www.ebi.ac.uk/arrayexpress/experiments/ E-MTAB-5385/). The latter of the above-mentioned changes were also observed in the comparison of adult breast and facial fibroblasts. This was expected for the neural crest genes; however, the observation of changes in organs (for example, heart development) were not anticipated. The largest contribution to detection of heart development by GSEA had the heart and neural crest derivatives expressed 2 (Hand2) gene, a transcription factor involved in the development of various organs. Notably, the Hand2 gene was associated with cleft palate in mice (40). No significant dysregulation of the GO terms associated with TNF signaling was observed, which may have been caused by a lack of statistical strength. TGF- $\beta$ signaling, however, reoccurred in the GSEA analyses on the GO terms and KEGG pathways; therefore, this pathway became the study focus (Fig. 9).

Virtually no differences between the transcription of genes in NCF and OCCF were observed. The NCFs significantly differed from fibroblasts prepared from scar located on the body in 994 genes and a similar difference (807 genes) was observed during the comparison of OCCFs and adult scar fibroblasts (Fig. 6). The GSEA analysis results were similar to the comparison of the adult fibroblasts to NCF and OCCF, with a notable exception of the p53 signaling pathway and apoptosis (sestrin 1, cyclin dependent kinase inhibitor $2 \mathrm{~A}$ and phorbol-12-myristate-13-acetate-induced protein 1). Finally, only subtle differences between NCF and OCCF were observed: only two genes were significantly different between these fibroblasts and only one of them was protein-coding (structural maintenance of chromosomes 6).

Differences in sensibility to TGF- $\beta$ inhibition. TGF- $\beta$ signaling was determined as the most likely difference between adult and child fibroblasts. Furthermore, a high incidence of myofibroblasts was observed in cultures of NCFs and OCCFs, which supported the decision to focus the study on the TGF family. No differences in the expression level of TGF- $\beta 1$ were observed; however, the activity of TGF- $\beta 2$, TGF- $\beta 3$, and receptor TGF- $\beta R 2$ in the NCF and OCCF groups appears to be functionally relevant (Fig. 8A-C). In NCFs and OCCFs, the activity of the SMAD3 gene, a product of which is downstream of the TGF- $\beta$ signaling cascade, supported this finding (Fig. 8E). Certain differences between adult fibroblasts obtained from breast and facial samples were observed, namely in the case of TGF- $\beta 3$ and TGF- $\alpha$ (Fig. 8B and D). In addition, changes in the transcriptional activity of the genes that likely regulate 


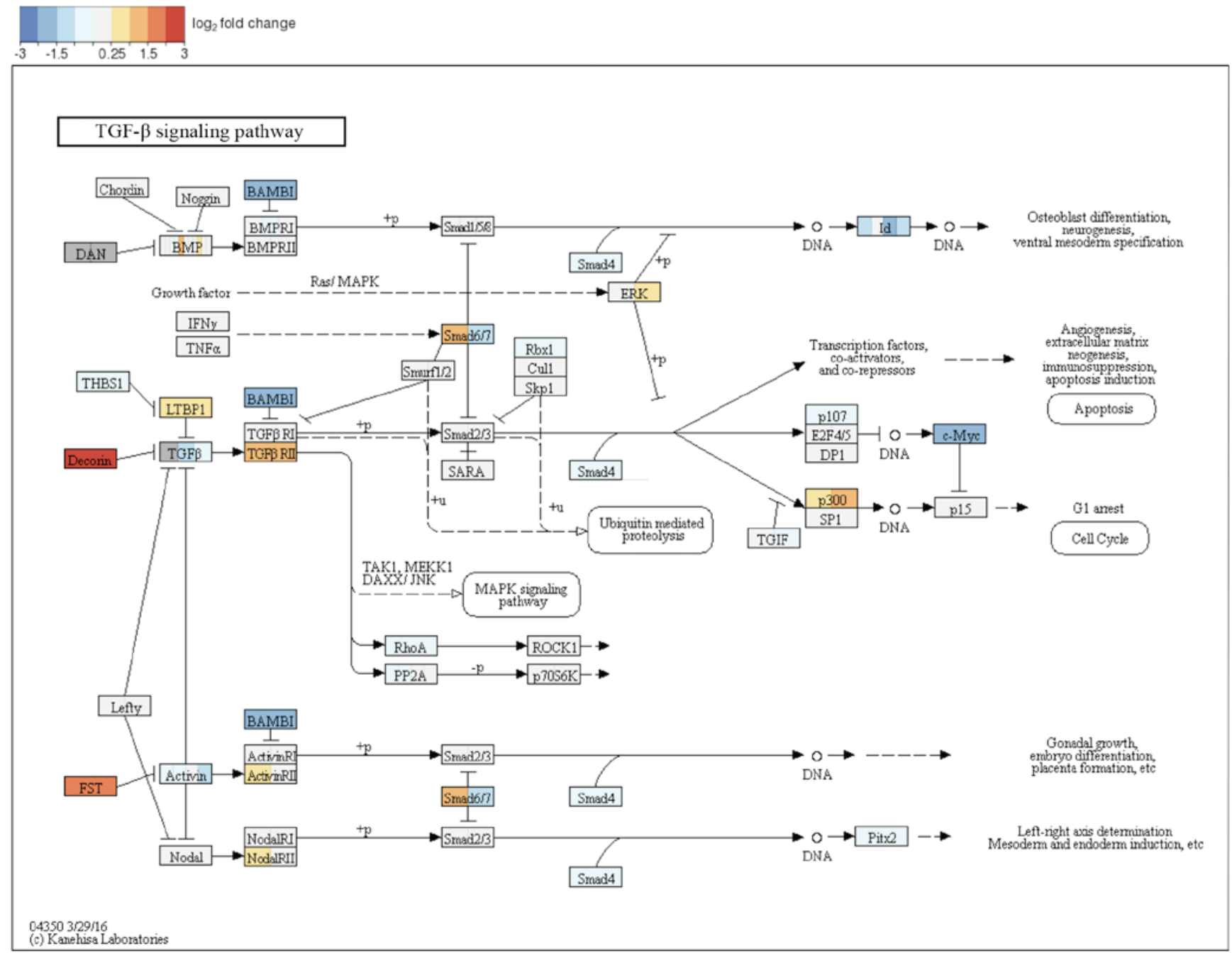

Figure 9. Kyoto Encyclopedia of Genes and Genomes and TGF- $\beta$ signaling pathway with changes between adult facial fibroblasts and neonate fibroblasts denoted by color code. TGF- $\beta$ family member binds to the type II receptor and recruits type I, whereby type II receptor phosphorylates and activates type I. The type I receptor, in turn, phosphorylates receptor-activated Smads (R-Smads: Smad1, Smad2, Smad3, Smad5 and Smad8). Once phosphorylated, R-Smads associate with the co-mediator Smad, Smad4 and the heteromeric complex then translocates into the nucleus. In the nucleus, Smad complexes activate specific genes via cooperative interactions with other DNA-binding and coactivator (or co-repressor) proteins. TGF- $\beta$, transforming growth factor- $\beta$; Smad, SMAD family member.

TGF- $\beta$ signaling (CD2AP, CD34, HIF1A, CD24, PTGS2 and $M E T$ ) were observed. The role of TGF- $\beta 3$ and inhibitor of TGF- $\beta$ signaling in the growth of NCFs and OCCFs, and adult fibroblasts was also analyzed. The results demonstrated that TGF- $\beta 3$ exerted no influence on the cell culture growth; however, the adult cells and OCCF were sensitive to TGF- $\beta$ receptor inhibition. NCF were insensitive in this case (Fig. 10).

\section{Discussion}

The observation that NCF and OCCF strongly express SMA, and are therefore regarded as myofibroblasts, represents the main finding of the present study. Myofibroblasts frequently originate as a result of the transition of local fibroblasts in various locations. This transition appears to be triggered by an excess of TGF- $\beta(37,41,42)$. Myofibroblasts also represent the common element of tumour stroma, and positively influence tumour growth and spread. Furthermore, similar cells are present in granulation tissue of the wound and influence the process of healing, including wound contraction (27). The observations at mRNA level from the present study demonstrate dysregulation of TGF- $\beta$ signaling with upregulation of transcripts for TGF- $\beta 2$ and TGF- $\beta 3$, and downregulation of receptor, TGF- $\beta$ R2. Etiopathogenesis of the orofacial cleft is associated with aberrant TGF- $\beta$ signaling (43-45). In addition, TGF- $\beta$ appears to influence the phenotype of fibroblasts isolated from cleft palate (46). Low production of IL-6 and IL-8 is associated with scarless wound healing and a particularly low secretion of IL-6 and IL-8 is a specific feature of normal neonatal fibroblasts $(47,48)$. This data indicates that NCFs and OCCFs are influenced by the cleft status.

Expression profiles of fibroblasts isolated from the breast and face are distinct, this difference is maintained despite the orofacial cleft status and age of the donor. The facial fibroblasts originate from neural crest derived ectomesenchyme and, in comparison with fibroblasts of other origin and different nature, they are quite devoid of classical HOX gene expression (49-51). The present analysis demonstrated low activity of a subgroup of homeobox genes in facial fibroblasts when compared with fibroblasts from the breast tissue. 


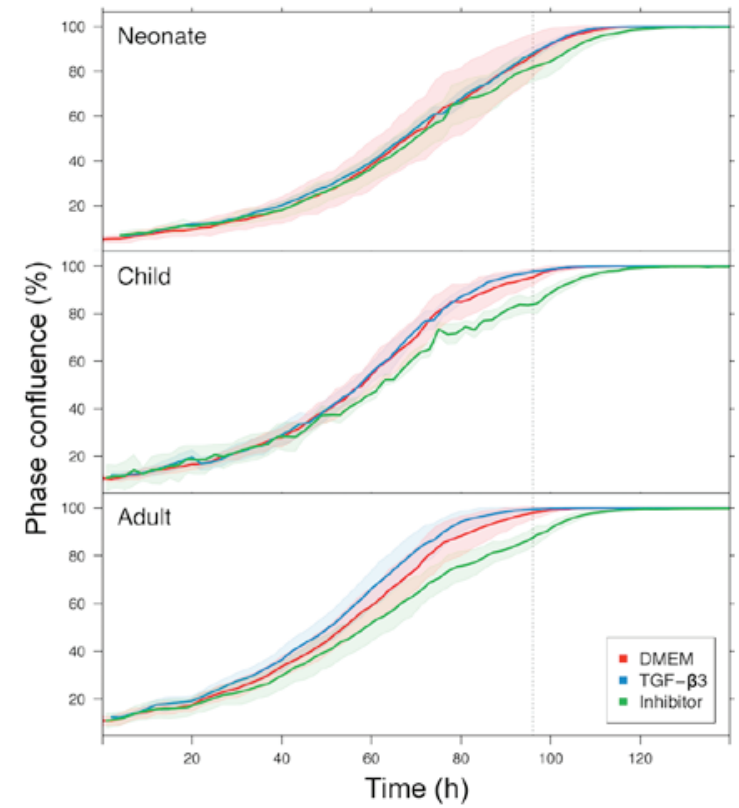

Figure 10. Effect of TGF- $\beta 3$ and TGF- $\beta$ inhibitor on growth kinetics of neonate, child, and adult fibroblasts measured using IncuCyte. The time dependence of cell confluency is represented. The shadows determine the spread of the technical replicates. Note the insensitivity of neonatal cells to inhibition. TGF- $\beta$, transforming growth factor- $\beta$; DMEM, Dulbecco's modified Eagle's medium.

Based upon the analysis performed in the present study, the boundary between improved and almost scarless healing as referred to by aesthetic surgeons in cleft lip restoration (52) was not defined. However, the therapeutic window may be larger or site specific, as demonstrated by regeneration of the digit tip (53). The expression profiles of NCFs and OCCFs are practically identical and it must be noted that they differ from normal fibroblasts due to the high incidence of SMA-positive fibroblasts/myofibroblasts, typical of wound healing and stromal cancer-associated fibroblasts (27). Similar profiles of cleft palate and cancer have also been observed by others (54). Cancer-associated fibroblasts produce IL- 6 and IL-8, which influence differentiation patterns of human keratinocytes to elements with low differentiation status (38). NCF/OCCF also produce these factors, and secrete TGF- $\beta 3$ and exhibit a reduced quantity of TGF- $\beta$ R2, which is associated with antifibrotic and anti-myofibroblast formation activity (55-59).

In conclusion, fibroblasts isolated from the cleft lip, as the most frequent congenital malformation of the face, reflect the disease status. Expression levels of nestin and changes in TGF- $\beta$ signaling, which influence SMA expression levels in fibroblasts, participate in improved wound healing following neonatal cheiloplasty. Furthermore, the neural crest ectomesenchyme-derived fibroblasts significantly differ from fibroblasts isolated from the chest.

\section{Acknowledgements}

The authors would like to thank Marie Jindráková and Šárka Kocourková, MSc, for their technical assistance. The present study was supported by the Grant Agency of the Czech Republic (grant. no. P304-13-20293S), Charles University (project of Specific University Research and PROGRES Q28/F1 and UNCE 204013), Ministry of Education, Youth and Sports of CR within the National Sustainability Program II (project BIOCEV-FAR; registration no. LQ1604), and project BIOCEV (grant no. CZ.1.05/1.1.00/02.0109). The present study is a result of the following project implementation: The equipment for metabolomic and cell analyses (grant no. CZ.1.05/2.1.00/19.0400) supported by the Research and Development for Innovations Operational Program, co-financed by the European regional development fund and the state budget of the Czech Republic. Access to computing and storage facilities, owned by parties and projects contributing to the National Grid Infrastructure MetaCentrum, were provided under the program Projects of Large Research, Development and Innovations Infrastructures (CESNET LM2015042) was greatly appreciated.

\section{References}

1. Panamonta V, Pradubwong S, Panamonta M and Chowchuen B: Global Birth Prevalence of Orofacial Clefts: A Systematic Review. J Med Assoc Thai 98 (Suppl 7): S11-S21, 2015.

2. Dunkhase E, Ludwig KU, Knapp M, Skibola CF, Figueiredo JC, Hosking FJ, Ellinghaus E, Landi MT, Ma H, Nakagawa $\mathrm{H}$, et al: Nonsyndromic cleft lip with or without cleft palate and cancer: Evaluation of a possible common genetic background through the analysis of GWAS data. Genom Data 10: 22-29, 2016.

3. Galinier P, Salazard B, Deberail A, Vitkovitch F, Caovan C, Chausseray G, Acar P, Sami K, Guitard J and Smail N: Neonatal repair of cleft lip: A decision-making protocol. J Pediatr Surg 43: 662-667, 2008

4. Harris PA, Oliver NK, Slater P, Murdoch L and Moss AL: Safety of neonatal cleft lip repair. J Plast Surg Hand Surg 44: 231-236, 2010.

5. Borský J, Velemínská J, Jurovčík M, Kozák J, Hechtová D, Tvrdek M, Černý M, Kabelka Z, Fajstavr J, Janota J, et al: Successful early neonatal repair of cleft lip within first 8 days of life. Int J Pediatr Otorhinolaryngol 76: 1616-1626, 2012.

6. Dadáková M, Cagáňová V, Dupej J, Hoffmannová E, Borský J and Velemínská J: Three-dimensional evaluation of facial morphology in pre-school cleft patients following neonatal cheiloplasty. J Craniomaxillofac Surg 44: 1109-1116, 2016.

7. Hoffmannova E, Bejdová Š, Borský J, Dupej J, Cagáňová V and Velemínská J: Palatal growth in complete unilateral cleft lip and palate patients following neonatal cheiloplasty: Classic and geometric morphometric assessment. Int J Pediatr Otorhinolaryngol 90: 71-76, 2016.

8. Coolen NA, Schouten KCWM, Boekema BKHL, Middelkoop E and Ulrich MMW: Wound healing in a fetal, adult, and scar tissue model: A comparative study. Wound Repair Regen 18: 291-301, 2010.

9. Yates CC, Hebda P and Wells A: Skin wound healing and scarring: Fetal wounds and regenerative restitution. Birth Defects Res C Embryo Today 96: 325-333, 2012.

10. Kieran I, Knock A, Bush J, So K, Metcalfe A, Hobson R, Mason T, O'Kane S and Ferguson M: Interleukin-10 reduces scar formation in both animal and human cutaneous wounds: Results of two preclinical and phase II randomized control studies. Wound Repair Regen 21: 428-436, 2013.

11. Gourevitch D, Kossenkov AV, Zhang Y, Clark L, Chang C, Showe LC and Heber-Katz E: Inflammation and its correlates in regenerative wound healing: An alternate perspective. Adv Wound Care (New Rochelle) 3: 592-603, 2014.

12. King A, Balaji S, Le LD, Crombleholme TM and Keswani SG: Regenerative wound healing: The role of interleukin-10. Adv Wound Care (New Rochelle) 3: 315-323, 2014.

13. Walraven $\mathrm{M}$, Talhout W, Beelen RHJ, van Egmond $\mathrm{M}$ and Ulrich MM: Healthy human second-trimester fetal skin is deficient in leukocytes and associated homing chemokines. Wound Repair Regen 24: 533-541, 2016.

14. Lu L, Saulis AS, Liu WR, Roy NK, Chao JD, Ledbetter S and Mustoe TA: The temporal effects of anti-TGF-beta1, 2, and 3 monoclonal antibody on wound healing and hypertrophic scar formation. J Am Coll Surg 201: 391-397, 2005.

15. Schmid P, Itin P, Cherry G, Bi C and Cox DA: Enhanced expression of transforming growth factor-beta type I and type II receptors in wound granulation tissue and hypertrophic scar. Am J Pathol 152: 485-493, 1998. 
16. Ashcroft GS, Yang X, Glick AB, Weinstein M, Letterio JL, Mizel DE, Anzano M, Greenwell-Wild T, Wahl SM, Deng C, et al: Mice lacking Smad3 show accelerated wound healing and an impaired local inflammatory response. Nat Cell Biol $1:$ 260-266, 1999.

17. Dang CM, Beanes SR, Soo C, Ting K, Behaim P, Hendrick MH and Lorenz HP: Decreased expression of growth factor isoforms and receptors during scarless repair. Plast Reconstr Surg 111: 1969-1979, 2003.

18. Dang CM, Beanes SR, Lee H, Zhang X, Soo C and Ting K: Scarless fetal wounds are associated with an increased matrix metalloproteinase-to-tissue-derived inhibitor of metalloproteinase ratio. Plast Reconstr Surg 111: 2273-2285, 2003.

19. Tan KK, Salgado G, Connolly JE, Chan JK and Lane EB: Characterization of fetal keratinocytes, showing enhanced stem cell-like properties: A potential source of cells for skin reconstruction. Stem Cell Reports 3: 324-338, 2014.

20. Krejčí E, Kodet O, Szabo P, Borský J, Smetana K Jr, Grim M and Dvořánková B: In vitro differences of neonatal and later postnata keratinocytes and dermal fibroblasts. Physiol Res 64: 561-569, 2015

21. Barrandon Y and Green H: Cell size as a determinant of the clone-forming ability of human keratinocytes. Proc Natl Acad Sci USA 82: 5390-5394, 1985

22. Shin DM, Suszynska M, Mierzejewska K, Ratajczak J and Ratajczak MZ: Very small embryonic-like stem-cell optimization of isolation protocols: An update of molecular signatures and a review of current in vivo applications. Exp Mol Med 45: e56, 2013

23. Mateu R, Živicová V, Krejčí ED, Grim M, Strnad H, Vlček C, Koláŕ M, Lacina L, Gál P, Borský J, et al: Functional differences between neonatal and adult fibroblasts and keratinocytes: Donor age affects epithelial-mesenchymal crosstalk in vitro. Int J Mol Med 38: 1063-1074, 2016

24. Pratsinis H, Armatas A, Dimozi A, Lefaki M, Vassiliu P and Kletsas D: Paracrine anti-fibrotic effects of neonatal cells and living cell constructs on young and senescent human dermal fibroblasts. Wound Repair Regen 21: 842-851, 2013.

25. Gilbert SF: The central nervous system and the epidermis In: Developmental Biology, 6th edition. Sunderland MA (ed) Sinauer Associates, Sunderland, pp379-410, 2000.

26. Ng YZ, Pourreyron C, Salas-Alanis JC, Dayal JH, Cepeda-Valdes R, Yan W, Wright S, Chen M, Fine JD, Hogg FJ, et al: Fibroblastderived dermal matrix drives development of aggressive cutaneous squamous cell carcinoma in patients with recessive dystrophic epidermolysis bullosa. Cancer Res 72: 3522-3534, 2012

27. Lacina L, Plzak J, Kodet O, Szabo P, Chovanec M, Dvorankova B and Smetana K Jr: Cancer microenvironment: What can we learn from the stem cell niche. Int J Mol Sci 16: 24094-24110, 2015.

28. Kruger NJ: Basic protein and peptide protocols. In: Methods in Molecular Biology. Walker JM (ed). Vol.32, Humana Press Inc., Totowa, NJ, pp9-15, 1994.

29. Inman GJ, Nicolás FJ, Callahan JF, Harling JD, Gaster LM Reith AD, Laping NJ and Hill CS: SB-431542 is a potent and specific inhibitor of transforming growth factor-beta superfamily type I activin receptor-like kinase (ALK) receptors ALK4, ALK5, and ALK7. Mol Pharmacol 62: 65-74, 2002.

30. Carvalho BS and Irizarry RA: A framework for oligonucleotide microarray preprocessing. Bioinformatics 26: 2363-2367, 2010

31. Ritchie ME, Phipson B, Wu D,Hu Y,Law CW, Shi W and Smyth GK: limma powers differential expression analyses for RNA-sequencing and microarray studies. Nucleic Acids Res 43: e47, 2015.

32. Huber W, Carey VJ, Gentleman R, Anders S, Carlson M, Carvalho BS, Bravo HC, Davis S, Gatto L, Girke T, et al: Orchestrating highthroughput genomic analysis with Bioconductor. Nat Methods 12: $115-121,2015$

33. RC Team: R: A Language and environment for statistical computing R Foundation for Statistical Computing, Vienna, Austria, 2016. https://www.R-project.org/.

34. Storey JD and Tibshirani R: Statistical significance for genomewide studies. Proc Natl Acad Sci USA 100: 9440-9445, 2003.

35. Kanehisa M, Furumichi M, Tanabe M, Sato Y and Morishima K KEGG: New perspectives on genomes, pathways, diseases and drugs. Nucleic Acids Res 45: D353-D361, 2017.

36. Gene Ontology Consortium: Gene Ontology Consortium: Going forward. Nucleic Acids Res 43: D1049-D1056, 2015.

37. Dvořánková B, Szabo P, Lacina L, Gal P, Uhrova J, Zima T, Kaltner H, André S, Gabius HJ, Syková E, et al: Human galectins induce conversion of dermal fibroblasts into myofibroblasts and production of extracellular matrix: Potential application in tissue engineering and wound repair. Cells Tissues Organs 194: 469-480, 2011
38. Kolář M, Szabo P, Dvořánková B, Lacina L, Gabius HJ, Strnad H, Sáchová J, Vlček C, Plzák J, Chovanec M, et al: Upregulation of IL-6, IL-8 and CXCL-1 production in dermal fibroblasts by normal/malignant epithelial cells in vitro: Immunohistochemical and transcriptomic analyses. Biol Cell 104: 738-751, 2012.

39. Holland PWH, Booth HAF and Bruford EA: Classification and nomenclature of all human homeobox genes. BMC Biol 5: 47, 2007.

40. Xiong W, He F, Morikawa Y, Yu X, Zhang Z, Lan Y, Jiang R, Cserjesi $\mathrm{P}$ and Chen Y: Hand2 is required in the epithelium for palatogenesis in mice. Dev Biol 330: 131-141, 2009.

41. Hinz B, Phan SH, Thannickal VJ, Galli A, Bochaton-Piallat ML and Gabbiani G: The myofibroblast: One function, multiple origins. Am J Pathol 170: 1807-1816, 2007.

42. Brenmoehl J, Miller SN, Hofmann C, Vogl D, Falk W, Schölmerich J and Rogler G: Transforming growth factor- $\beta 1$ induces intestinal myofibroblast differentiation and modulates their migration. World J Gastroenterol 15: 1431-1442, 2009.

43. Ito Y, Yeo JY, Chytil A, Han J, Bringas P Jr, Nakajima A, Shuler CF, Moses HL and Chai Y: Conditional inactivation of Tgfbr 2 in cranial neural crest causes cleft palate and calvaria defects. Development 130: 5269-5280, 2003.

44. Ichikawa E, Watanabe A, Nakano Y, Akita S, Hirano A, Kinoshita A, Kondo S, Kishino T, Uchiyama T, Niikawa N, et al: PAX9 and TGFB3 are linked to susceptibility to nonsyndromic cleft lip with or without cleft palate in the Japanese: Population-based and family-based candidate gene analyses. J Hum Genet 51: 38-46, 2006.

45. Iwata J, Parada $C$ and Chai Y: The mechanism of TGF- $\beta$ signaling during palate development. Oral Dis 17: 733-744, 2011.

46. Baroni T, Bellucci C, Lilli C, Pezzetti F, Carinci F, Becchetti E, Carinci P, Stabellini G, Calvitti M, Lumare E, et al: Retinoic acid, GABA-ergic, and TGF- $\beta$ signaling systems are involved in human cleft palate fibroblast phenotype. Mol Med 12: 237-245, 2006.

47. Satish L and Kathju S: Cellular and molecular characteristics of scarless versus fibrotic wound healing. Dermatol Res Pract 2010: 790234, 2010

48. Bermudez DM, Canning DA and Liechty KW: Age and proinflammatory cytokine production: Wound-healing implications for scar-formation and the timing of genital surgery in boys. J Pediatr Urol 7: 324-331, 2011

49. Whiting J: Craniofacial abnormalities induced by the ectopic expression of homeobox genes. Mutat Res 396: 97-112, 1997.

50. Creuzet S, Couly G and Le Douarin NM: Patterning the neural crest derivatives during development of the vertebrate head: Insights from avian studies. J Anat 207: 447-459, 2005.

51. Mallo $\mathrm{M}$ and Alonso CR: The regulation of Hox gene expression during animal development. Development 140: 3951-3963, 2013.

52. McHeik JN, Sfalli P, Bondonny JM and Levard G: Early repair for infants with cleft lip and nose. Int J Pediatr Otorhinolaryngol 70: 1785-1790, 2006.

53. Shieh SJ and Cheng TC: Regeneration and repair of human digits and limbs: Fact and fiction. Regeneration (Oxf) 2: 149-168, 2015.

54. Wang H, Qiu T, Shi J, Liang J, Wang Y, Quan L, Zhang Y, Zhang Q and Tao K: Gene expression profiling analysis contributes to understanding the association between non-syndromic cleft lip and palate, and cancer. Mol Med Rep 13: 2110-2116, 2016.

55. Eslami A, Gallant-Behm CL, Hart DA, Wiebe C, Honardoust D, Gardner H, Häkkinen L and Larjava HS: Expression of integrin alphavbeta6 and TGF-beta in scarless vs scar-forming wound healing. J Histochem Cytochem 57: 543-557, 2009.

56. Zhu X, Li L, Zou L, Zhu X, Xian G, Li H, Tan Y and Xie L: A novel aptamer targeting TGF- $\beta$ receptor II inhibits transdifferentiation of human tenon's fibroblasts into myofibroblast. Invest Ophthalmol Vis Sci 53: 6897-6903, 2012.

57. Chang Z, Kishimoto Y, Hasan A and Welham NV: TGF- $\beta 3$ modulates the inflammatory environment and reduces scar formation following vocal fold mucosal injury in rats. Dis Model Mech 7: 83-91, 2014

58. Sriram S, Gibson DJ, Robinson P, Pi L, Tuli S, Lewin AS and Schultz G: Assessment of anti-scarring therapies in ex vivo organ cultured rabbit corneas. Exp Eye Res 125: 173-182, 2014.

59. Liang C, Li X, Zhang L, Cui D, Quan X and Yang W: The anti-fibrotic effects of microRNA-153 by targeting TGFBR-2 in pulmonary fibrosis. Exp Mol Pathol 99: 279-285, 2015. 